\title{
Risk Assessment of a Synthetic Pyrethroid, Bifenthrin on Pulses
}

\author{
Irani Mukherjee $\cdot$ Ranbir Singh $\cdot$ J. N. Govil
}

Received: 20 July 2009/ Accepted: 13 January 2010/Published online: 29 January 2010

(C) The Author(s) 2010. This article is published with open access at Springerlink.com

\begin{abstract}
This work was undertaken to determine the preharvest interval of bifenthrin and to minimize its residues in pulses and thereby ensure consumer safety and avoid non-compliance in terms of residues violations in export market. Furthermore the residue dynamics in the soil under pulses was explored to assess the environmental safety. The residues of bifenthrin dissipated following first order kinetics. The residues in harvest time grains were below the maximum residue limit (MRL) of $0.02 \mathrm{mg} / \mathrm{kg}$ applicable for European Union. In soil the degradation rate was fast with a half life of 2-3 days. This work is of high practical significance to the domestic and export pulse industry of India to ensure safety compliance in respect of bifenthrin residues, keeping in view the requirements of international trade.
\end{abstract}

Keywords Bifenthrin - Dissipation kinetics - Pulses . Chickpea $\cdot$ Pigeon pea $\cdot$ Soil

Bifenthrin, ((2-methyl-1,1-biphenyl-3-y1)-methyl-3-(2-chloro-3, 3,3-trifluoro-1-propenyl)-2,2-dimethyl cyclopropanecarboxylate, Fig. 1, Table 1) is an insecticide with contact and

I. Mukherjee ( $\square)$

Division of Agricultural Chemicals, Agricultural Research Service, Indian Agricultural Research Institute, New Delhi, India e-mail: mukrj_irani@yahoo.com

\section{R. Singh}

Division of Agronomy, Agricultural Research Service, Indian Agricultural Research Institute, New Delhi, India

J. N. Govil

Division of Genetics, Agricultural Research Service,

Indian Agricultural Research Institute, New Delhi, India stomach poison. It has broad range of activity, against foliar pests including Coloeptera, Diptera, Heteroptera, lepidoptera, Homoptera, Othorptera among others. Crops include cereals, cotton, pulses, vegetables and ornamentals. It affects the nervous system of insects. Products containing bifenthrin include Talstar, Capture, Brigade, Bifenthrine, among others. The Bifenthrin Molecule, a 4th generation pyrethroid, was discovered and developed by FMC Corporation Pty Ltd it. Bifenthrin is virtually insoluble in water with a solubility of $0.1 \mathrm{mg} / \mathrm{l}$. Given its low solubility, bifenthrin has high persistence in soil (half life $=7$ days8 months) and consequently has long residual termiticide action currently registered in the market. The material safety data sheet (MSDS) for FMC Corp.'s Biflex (Bifenthrin's trade name) shows carcinogenic qualities to be virtually zero. It is highly toxic to fish, and like most pyrethroids, is also an ATPase inhibitor. Aquatic vertebrates are much more sensitive to ATPase inhibitors than terrestrial vertebrates due to their high dependence on ATP synthesis in the gills to maintain osmotic balance. Based on these risk assessments, EPA concludes that there is a reasonable certainty that no harm will result to the general population and to infants and children from aggregate exposure to bifenthrin residues. Pyrethroids affect the sodium ion channel in both the peripheral and central nervous system of insects, initially stimulating nerve cells and eventually causing paralysis (Ware 2000).

The environmental fate of bifenthrin is a direct result of its chemical properties and the biotic and abiotic factors to which it is exposed. The major biotic pathway of bifenthrin degradation is hydrolysis into 4'-hydroxy bifenthrin (Fecko 1999). Minor pathways of biotic degradaion include ester cleavage, hydroxylation, and oxidation into benylphenoxy acid, BP alcohol, and BP aldehyde. In aqueous environments bifenthrin is usually adsorbed onto sediment and 
<smiles></smiles>

I<smiles>Cc1c(C=O)cccc1-c1ccccc1</smiles>

II

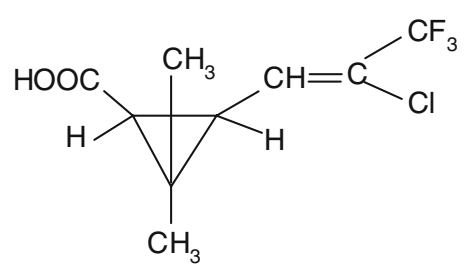

III
Fig. 1 Bifenthrin (I) and its metabolites II and III

suspended particles. In addition, hydrolysis forms 4'hydroxy bifenthrin. In soils, the major degradation pathway involves the formation of $4^{\prime}$-hydroxy bifenthrin and photolysis and ester cleavage produce BP acid, BP alcohol, and TFP.

Bifenthrin is effective for control of insect pets of cotton (Ali and Karim 1994), vegetables (Gupta et al. 2009), fruits (Reddy and Rao 2002), and in public health for control of mosquitoes (Mittal et al. 2002). It has shown good bioefficacy against insect pests of brinjal (Sudhakar et al. 1998) and tomato (Rushtapakornchai and Petchwichit 1996). Efficacy of different insecticides as foliar application was studied against mustard aphid Lipaphis erysimi (Kalt) by Rana et al. (2007). All tested insecticides performed better against aphid as compared to untreated plots and were at par with one another as compared to DC-Tron Plus and check. Carbosulfan proved as the best with $94.34 \%$ aphid. Population reduction, followed by bifenthrin, imidacloprid and DC-Tron Plus with 94.20, 92.66 and 53.42\% reduction, respectively. Based on these risk assessments, EPA concludes that there is a reasonable certainty that no harm will result to the general population and to infants and children from aggregate exposure to bifenthrin residues. There are however, no reports of the behavior and persistence of bifenthrin on pulse crops like chickpea (cicer aretinium $\mathrm{L}$ ) and pigeon pea (cajanus cajan L). The pulse crop is infested by a large number of insect pests, like pod borers, aphids, jassids and pod fly, which results in loss in yield. The synthetic pyrethriods have proved to be effective in the control of resistant insect pests of pulse crops (Mukherjee et al. 2007). The consumption of synthetic pyrethroids has increased significantly with the decline in the use of organochlorine pesticides like lindane and endosulfan, which were used for the control of insect pests of pulses. The synthetic pyrethroids represent the most popular class of insecticides today. The presence of pesticides residues in vegetables, fruits and green leaves above the maximum limit is of concern to human health due to the toxic nature of the pesticides. Hence, it is imperative to evaluate the pesticide schedule on edible crops for quantification of residues. This paper presents the behavior of bifenthrin in chickpea and pigeon pea.

\section{Materials and Methods}

The maximum temperature during chickpea crop was 27.2 and $12.0^{\circ} \mathrm{C}$, respectively with relative humidity of $32 \%$. Average sunshine hours recorded was 9.50. There was no rainfall during the period of study. In case of pigeon pea the maximum and minimum temperatures were 29.8 and $16.9^{\circ} \mathrm{C}$, respectively, with relative humidity of $69 \%$. Average sunshine hours recorded was 5 . The rainfall recorded during the period was $68.6 \mathrm{~mm}$. A field trial was conducted in a randomized block design during 2007-2008. Pigeon pea (var Pusa 855) and chickpea crop (var Pusa 256) were raised
Table 1 Important properties of bifenthrin

\begin{tabular}{|c|c|}
\hline Property & Bifenthrin \\
\hline CAS number & $82657-04-3$ \\
\hline Chemical class & Pyrethroid \\
\hline Chemical name & $\begin{array}{l}\text { (2-methyl-1,1-biphenyl-3-y1)-methyl-3-(2-chloro-3,3,3-trifluoro-1-propenyl)-2, } \\
\text { 2-dimethyl cyclopropanecarboxylate }\end{array}$ \\
\hline $\begin{array}{l}\text { Relative molecular } \\
\text { mass }\end{array}$ & 422.9 \\
\hline $\begin{array}{l}\text { Vapor pressure } \\
(\mathrm{m} \mathrm{Pa})\end{array}$ & 0.024 \\
\hline $\begin{array}{l}\text { Aqueous } \\
\text { Solubility }(\mathrm{mg} / \mathrm{l})\end{array}$ & 0.1 \\
\hline $\log K_{\mathrm{ow}}$ & $>6$ \\
\hline
\end{tabular}


in the fields of Indian Agricultural Research Institute, New Delhi following good agricultural practices of the region. The plot size was $6 \mathrm{~m}^{2}$ for each replicate. Pigeon pea was grown during Khariff (May to October) season, while chickpea was grown in the Rabi season (November to April). Bifenthrin formulation, Talstar 10\% was applied @ 25.0 and $50.0 \mathrm{~g}$ a.i./ha in $750 \mathrm{~L}$ water (Treatment $\mathrm{T} 1$ and $\mathrm{T} 2$ ) at $50 \%$ pod formation stage in both chickpea and pigeon pea. The experiment was carried out in triplicate for each crop and a control plot was kept aside in which no pesticide was applied.

Analytical standard of bifenthrin was obtained by liquidliquid partitioning of the formulation, followed by column chromatography. The oil obtained was recrystallized from hexane-acetone. The stock solution of bifenthrin was prepared in hexane at $1 \mathrm{mg} / \mathrm{mL}$ and stored at $4^{\circ} \mathrm{C}$. Working standards were prepared by appropriate dilutions. Green pod samples of both chickpea and pigeon pea and soil were collected from each replicate plot, $1 \mathrm{~h}$ after application of the pesticide, and subsequently at periodic intervals of 1, 3, 5, 7, 10 and 15 days and grains and soil at harvest. The physiochemical parameters of IARI soil is given in Table 2. A total of 50-g samples of green pods and soil and $25 \mathrm{~g}$ grains were spiked in triplicate at two concentrations, 0.5 and $1.0 \mu \mathrm{g} / \mathrm{g}$ level. The limit of quantification carried out by fortification at $0.1 \mu \mathrm{g}$. The samples were extracted and cleaned as given below. A total of 50-g representative sub samples of green pods were extracted with acetone $(3 \times 50 \mathrm{~mL})$ in a Waring blender. The extract was concentrated under reduced pressure and transferred to a separatory funnel and saline water $(10 \%, 150 \mathrm{~mL})$ was added. The pesticide was exchanged into organic phase by liquid-liquid partitioning with dichloromethane $(3 \times 50 \mathrm{~mL})$. The organic solvent was concentrated under reduced pressure and then subjected to clean up (Mukherjee et al. 2007). The harvest time grain samples were extracted in a Soxhlet extractor for $4 \mathrm{~h}$ with $300 \mathrm{~mL}$ of a mixture of hexane-acetone (1:1). The extract of the grain sample was evaporated completely under vacuum, dissolved in hexane $(40 \mathrm{~mL})$ and then exchanged into acetonitrile $\left(3^{\prime} 40 \mathrm{~mL}\right)$, to remove the oil from the grains. The acetonitrile portion was further diluted with saline water $(2 \%, 600 \mathrm{~mL})$ and then partitioned into dichloromethane $\left(3^{\prime} 30 \mathrm{~mL}\right)$. The organic solvent was evaporated, dissolved in, hexane-acetone $(9+1)$ and subjected to clean up. A total of 50-g representative sub samples of soil was extracted with acetone $(3 \times 50 \mathrm{~mL})$ by shaking in a horizontal shaker in a Waring blender. The extract was concentrated under reduced pressure and transferred to a separatory funnel and saline water $(10 \%, 150 \mathrm{~mL})$ was added. The pesticide was exchanged into organic phase by liquid-liquid partitioning with dichloromethane $(3 \times 50 \mathrm{~mL})$. The organic solvent was concentrated under reduced pressure and then subjected to clean up (Mukherjee et al. 2007).
The concentrate $(5 \mathrm{~mL})$ was subjected to column clean up. The glass column $(1.5 \mathrm{~mm} \times 45 \mathrm{~cm})$ was packed with anhydrous sodium sulfate $(1 \mathrm{~g})+$ neutral alumina $(2 \mathrm{~g})+$ Florisil $(1 \mathrm{~g})+$ anhydrous sodium sulfate $(1 \mathrm{~g})$. The column was pre-washed with hexane $(30 \mathrm{~mL})$. The concentrate was loaded onto the column and eluted with a mixture of hexane-acetone $(1+1)$. The eluant was concentrated to dryness under rotary vacuum evaporator and made up in hexane before analysis by GLC. The recovery study was also carried out by varying the adsorbent to silica gel and alumina.

\section{GC Apparatus}

The quantitative estimation of bifenthrin was carried out using Varian CP-3800 Gas Liquid Chromatograph equipped with Ni 63 electron capture detector. The column CP Sil- $5(25 \mathrm{~m} \times 0.25 \mathrm{~mm}$ ID $\times 0.25 \mu)$. The column temperature was maintained column programmed from $220^{\circ} \mathrm{C}$ hold for 6 min increased @ $260^{\circ} \mathrm{C}$ hold for $10 \mathrm{~min}$. The injector and detector temperatures were 275 and $300^{\circ} \mathrm{C}$, respectively. The carrier gas flow in the column was $2 \mathrm{~mL} /$ min and backup flow was $27 \mathrm{~mL} / \mathrm{min}$. The total run time was $10 \mathrm{~min}$. The retentions time of bifenthrin under the conditions was $5.97 \mathrm{~min}$. The concentration of bifenthrin was calculated on the basis of a peak area from the calibration curve. Standard solutions of different concentrations $0.1,0.2,0.5,1.0,1.5$ and $2.0 \mu \mathrm{g} \mathrm{mL}^{-1}$ of bifenthrin was injected in the GLC and a calibration curve was drawn by plotting peak area vs concentration. Each injection was made thrice for all the concentrations so as to obtain the linearity range of the pesticide.

\section{Result and Discussions}

The recovery studies carried out at 0.5 and $1 \mu \mathrm{g}$ fortification level in green pods indicated that extraction with acetone followed by dichloromethane partitioning and column clean up over neutral alumina and Florisil gave the highest recovery in the ranged $85.6-92.0 \%$ (Table 3). The instrument detection limit was $0.01 \mathrm{mg} / \mathrm{kg}$ at signal: noise ratio $>3$ and the limit of quantification (LOQ) carried out at by fortification at $0.1 \mu \mathrm{g}$ gave percent recovery of 70.6 , signal: noise ratio $>10$, which is acceptable.

Samples were extracted with acetone, concentrated and then partitioned into dichloromethane. Column clean up over neutral alumina and Florisil and elution with 1:1 hexane: acetone as eluting solvent was found to be the best for cleanup of chickpea pigeon pea pods and soil. Residues of bifenthrin were estimated by GLC using electron capture detector. The persistence data is presented in Tables 4 and 5 . Average initial deposits of bifenthrin on chickpea at 
Table 2 Physico-chemical properties of the IARI soil

\begin{tabular}{|c|c|}
\hline Properties & Values \\
\hline \multicolumn{2}{|l|}{ Mechanical analysis } \\
\hline Sand $(\%)$ & 64.9 \\
\hline Silt $(\%)$ & 18.0 \\
\hline Clay $(\%)$ & 17.1 \\
\hline Textural class & Sandy loam \\
\hline Bulk density $\left(\mathrm{g} \mathrm{cm}^{-1}\right)$ & 1.45 \\
\hline Field capacity $(\%)$ & 17.61 \\
\hline \multicolumn{2}{|l|}{ Chemical properties } \\
\hline $\mathrm{pH}($ Soil $:$ Water $=1: 2.5)$ & 7.41 \\
\hline Electrical conductivity $\left(\mathrm{dsm}^{-1}\right)($ Soil $:$ Water $=1: 2.5)$ & 0.35 \\
\hline Cation exchange capacity $\left(\mathrm{Cmol}\left(\mathrm{p}^{+}\right) \mathrm{kg}^{-1}\right)$ & 7.35 \\
\hline Organic carbon $(\%)$ & 0.39 \\
\hline
\end{tabular}

Table 3 Recovery of bifenthrin from chickpea and pigeon pea

\begin{tabular}{lllllll}
\hline Adsorbent & $\begin{array}{l}\text { Amount added } \\
\left(\mu \mathrm{g} \mathrm{g}^{-1}\right)\end{array}$ & \multicolumn{2}{l}{ Amount recovered $\left(\mu \mathrm{g} \mathrm{g}^{-1}\right)$} & \multicolumn{2}{c}{$\begin{array}{l}\text { Average percent } \\
\text { recovery (SD) }\end{array}$} \\
\cline { 3 - 6 } & & $\mathrm{R}_{1}$ & $\mathrm{R}_{2}$ & $\mathrm{R}_{3}$ & Average (SD) \\
\hline Silica gel & 0.5 & 0.34 & 0.39 & 0.42 & 0.38 & $76.6(0.04)$ \\
Silica gel & 1 & 0.68 & 0.67 & 0.32 & 0.65 & $65.6(0.03)$ \\
Alumina & 0.5 & 0.37 & 0.4 & 0.45 & 0.40 & $81.3(0.04)$ \\
Alumina & 1 & 0.77 & 0.76 & 0.69 & 0.74 & $74.0(0.04)$ \\
Alumina + Florisil & 0.01 & 0.064 & 0.076 & 0.072 & 0.070 & $70.6(0.006)$ \\
Alumina + Florisil & 0.5 & 0.46 & 0.44 & 0.48 & 0.46 & $92.0(0.02)$ \\
Alumina + Florisil & 1 & 0.85 & 0.83 & 0.85 & 0.85 & $85.6(0.03)$ \\
\hline
\end{tabular}

* Extracting solvent: acetone, partitioning solvent: dichloromethane

recommended and double the recommended dose of application were 2.62 and $5.69 \mathrm{mg} / \mathrm{kg}$, respectively. Residues dissipated with time, at both the doses. At high dose residues of bifenthrin persisted up to 15 days, whereas at low dose no residues were found on 15th day samples (Table 4). Half-life values calculated following first order dissipation kinetics model were 4.30 and 2.89 days at recommended and double the recommended dose of application, respectively (Table 6). Initial residues in soil under chickpea crop recorded was 1.31 and $2.01 \mathrm{mg} / \mathrm{kg}$ at recommended and double the recommended dose of application. The residues dissipated with time to 0.02 and $0.08 \mathrm{mg} / \mathrm{kg}$ on 15 day after application and at harvest time the residues were below detectable limit $(<0.01 \mathrm{mg} / \mathrm{kg})$ in soil (Table 5). The half life of bifenthrin in soil was 2.50 and 3.01 days at recommended and double the recommended dose of application, respectively (Table 6).

Average initial deposits of bifenthrin on pigeon pea at recommended and double the recommended dose of application were 2.08 and $4.58 \mathrm{mg} / \mathrm{kg}$, respectively. Residues dissipated with time, at both the doses. At high dose residues of bifenthrin persisted up to 15 days, whereas at low dose no residues were found on 15th day samples (Table 4). Half-life values calculated following first order dissipation kinetics model was 3.34 days at low and high dose, respectively (Table 6). Initial residues in soil under pigeon pea crop recorded was 1.02 and $2.24 \mathrm{mg} / \mathrm{kg}$ at recommended and double the recommended dose of application. The residues dissipated with time to nondetectable $(<0.01 \mathrm{mg} / \mathrm{kg})$ and $0.05 \mathrm{mg} / \mathrm{kg}$ on 15 day after application and at harvest time the residues were below detectable limit $(<0.01 \mathrm{mg} / \mathrm{kg})$ in soil (Table 5). The half lives of bifenthrin in soil were 3.73 and 3.01 days at recommended and double the recommended dose of application, respectively.

It is imperative to quantify the residues of bifenthrin in soil as almost $50 \%$ of the pesticide falls on soil during foliar application. Literature reveals that Long persistence was observed for bifenthrin under both aerobic and anaerobic conditions, and the half-life ranged from 8 to 17 months at $20^{\circ} \mathrm{C}$ (Gan et al. 2005). Recent studies showed that synthetic pyrethroids (SPs) can move via surface runoff into aquatic systems. In the aqueous phase, bifenthrin was rapidly degraded by strains of Stenotrophomonas acidaminiphila, 
Table 4 Residues $(\mathrm{mg} / \mathrm{kg}$ ) of bifenthrin on chickpea and pigeonpea

\begin{tabular}{lllllllllll}
\hline $\begin{array}{l}\text { Days dose } \\
\text { (g ai/ha) }\end{array}$ & Commodity & 0 & 1 & 3 & 5 & 7 & 10 & 15 & $\begin{array}{l}\text { Harvest } \\
\text { grains }\end{array}$ \\
\hline 25 & Chickpea & 2.62 & 2.37 & 1.86 & 1.22 & 0.98 & 0.53 & ND & ND \\
50 & & 5.69 & 4.83 & 3.12 & 2.33 & 1.43 & 0.57 & 0.16 & ND \\
25 & Pigeon pea & 2.08 & 1.87 & 1.02 & 0.79 & 0.68 & 0.23 & ND & ND \\
50 & & 4.58 & 3.27 & 2.53 & 1.12 & 0.73 & 0.48 & 0.17 & ND \\
\hline
\end{tabular}

$\mathrm{ND}(<0.01 \mathrm{mg} / \mathrm{kg})$

Table 5 Residues $\left(\mathrm{mg} \mathrm{kg}^{-1}\right.$ ) of bifenthrin in soil under chickpea and pigeonpea crop

\begin{tabular}{llllllllll}
\hline $\begin{array}{l}\text { Days dose } \\
\text { (g ai/ha) }\end{array}$ & Commodity & 0 & 1 & 3 & 5 & 7 & 10 & $\begin{array}{l}\text { Harvest } \\
\text { time soil }\end{array}$ \\
\hline 25 & Chickpea soil & 1.31 & 1.13 & 0.8 & 0.61 & 0.43 & 0.16 & 0.02 & ND \\
50 & & 2.81 & 2.31 & 1.40 & 1.08 & 0.62 & 0.21 & 0.08 & ND \\
25 & Pigeon pea soil & 1.02 & 0.89 & 0.48 & 0.32 & 0.18 & 0.10 & ND & ND \\
50 & & 2.24 & 1.54 & 1.05 & 0.58 & 0.31 & 0.21 & 0.05 & ND \\
\hline
\end{tabular}

Table 6 Regression equation and half-life of bifenthrin on chickpea and pigeon pea

\begin{tabular}{lllll}
\hline Commodity & $\begin{array}{l}\text { Dose } \\
\text { (g ai/ha) }\end{array}$ & Y= & $\begin{array}{l}\text { RL50 } \\
\text { (days) }\end{array}$ & R2 \\
\hline Chickpea & 25 & $0.4447-0.0694 \mathrm{x}$ & 4.30 & 0.989 \\
& 50 & $0.8121-0.1041 \mathrm{x}$ & 2.89 & 0.9907 \\
Pigeon pea & 25 & $0.3389-0.0901 \mathrm{x}$ & 3.34 & 0.9572 \\
& 50 & $0.6152-0.0952 \mathrm{x}$ & 3.34 & 0.9839 \\
Chickpea soil & 25 & $2.25-0.1166 \mathrm{x}$ & 2.73 & 0.94 \\
& 50 & $2.47-0.1058 \mathrm{x}$ & 3.01 & 0.98 \\
Pigeon pea soil & 25 & $2.09-0.1289 \mathrm{x}$ & 2.50 & 0.97 \\
& 50 & $2.32-0.1073 \mathrm{x}$ & 3.01 & 0.99 \\
\hline
\end{tabular}

and the half-life $\left(\mathrm{t}_{1 / 2}\right)$ was reduced from $>700 \mathrm{~h}$ to 30 to $131 \mathrm{~h}$. Bifenthrin $\mathrm{t}_{1 / 2}$ was 343 to $466 \mathrm{~h}$ for a field sediment, and increased to 980 to $1,200 \mathrm{~h}$ for a creek sediment. Although SP-degrading bacteria may be widespread in aquatic systems, adsorption to sediment could render SPs unavailable to the degraders, thus prolonging their persistence (Lee et al. 2004). In order of decreasing toxicity of sediment-associated residues, the compounds tested were bifenthrin (average 10-d median lethal concentration $(\mathrm{LC50})=0.18 \mathrm{microg} / \mathrm{g}$ OC) (Amweg et al. 2005). Bifenthrin degraded at a much slower rate as compared to imidacloprid and chlorpyrifos and the presence of moisture did not have any significant effect on the degradation of bifenthrin in soil at the termiticidal application rate (Baskaran et al. 1999).

Residues of bifenthrin below the detectable limit in chickpea and pigeon pea harvest grains $(<0.01 \mathrm{mg} / \mathrm{kg})$. In India, maximum residue limit (MRL) of bifenthrin on has not been fixed, however, Codex MRL of bifenthrin on pulses is fixed as $0.02 \mathrm{mg} / \mathrm{kg}$. The residues are below the detectable limit in harvested grains at both low and high dose of application, the schedule is considered to be safe from toxicity point of view. The metabolites, 1RS, 3RS)-3-[(Z)2-chloro-3,3,3-trifluoroprop-1-enyl]-2,2-dimethyl cyclopropane carboxylic acid (TFP acid, Fig. 1, III) and 4'-OH bifenthrin, (4'-hydroxy-2-methylbiphenyl-3-yl)methyl (1RS, 3RS)-3-[(Z)-2-chloro-3,3,3-trifluoroprop-1-enyl]-2,2-dimethylcyclopropanecarboxylate were not detected in green pods and in soil at harvest, bifenthrin was found to be the major residue component. Similar finding were also observed in metabolism studies on apples, cotton seed and corn plants bifenthrin was found to be the predominant residue. No significant cis- trans-isomerisation and translocation of residues through the plant were observed (http://www.efsa.europa.eu).

The Acceptable daily Intake (ADI) of bifenthrin is 0.02mg kg-1 body weight (Tomlin 2006), toxicity class, WHOII, EPA-II. Considering the body weight of an average Indian person as $50 \mathrm{~kg}$, MPI (maximum permissible intake) of bifenthrin is $1.0 \mathrm{mg}$ person ${ }^{-1} \mathrm{day}^{-1}$. Further taking $250 \mathrm{~g}$ as pulse consumption for on Indian balanced diet and maximum residues of bifenthrin on chickpea green pods on day- 0 is $2.62 \mathrm{mg} \mathrm{kg}^{-1}$, in case of recommended dose $(25 \mathrm{~g}$ a.i. ha ${ }^{-1}$ ), the TMRC is found at $0.65 \mathrm{mg} \mathrm{person}^{-1}$ day $^{-1}$, while the residues on day-10 is $0.53 \mathrm{mg} \mathrm{kg}^{-1}$, the TMRC is found at $0.13 \mathrm{mg}$ person ${ }^{-1}$ day $^{-1}$, (Tables 7 and 8 ) both the values are low as compared to MPI value of $1.0 \mathrm{mg}^{\text {person }}{ }^{-1}$ day ${ }^{-1}$, which indicates that the schedule is safe. Therefore, bifenthrin treatment at recommended dose appears safe in plant protection schedules. Hence if applied at $25 \mathrm{~g}$ a.i./ha as foliar spray, will not result in residue accumulation. However even if higher dose (50 g a.i./ha) is also intended, the 
Table 7 Theoretical Maximum residue Contribution in Chickpea and Pigeon pea

\begin{tabular}{|c|c|c|c|c|c|c|c|c|}
\hline Days & $\begin{array}{l}\text { Residues in } \\
\text { chickpea } \\
\left(\mathrm{mg} \mathrm{kg}^{-1}\right)\end{array}$ & $\begin{array}{l}\text { TMRC mg } \\
\text { person }^{-1} \\
\text { day }^{-1}\end{array}$ & $\begin{array}{l}\text { Residues in } \\
\text { chickpea } \\
\left(\mathrm{mg} \mathrm{kg}^{-1}\right)\end{array}$ & $\begin{array}{l}\text { TMRC mg } \\
\text { person }^{-1} \\
\text { day }^{-1}\end{array}$ & $\begin{array}{l}\text { Residues in } \\
\text { pigeon pea } \\
\left(\mathrm{mg} \mathrm{kg}^{-1}\right)\end{array}$ & $\begin{array}{l}\text { Calculated TMRC } \\
\text { mg person }^{-1} \\
\text { day }^{-1}\end{array}$ & $\begin{array}{l}\text { Residues in } \\
\text { Pigeon pea } \\
\left(\mathrm{mg} \mathrm{kg}^{-1}\right)\end{array}$ & $\begin{array}{l}\text { Calculated TMRC } \\
\text { mg person }^{-1} \\
\text { day }^{-1}\end{array}$ \\
\hline 0 & 2.62 & 0.655 & 5.69 & 1.425 & 2.08 & 0.52 & 4.58 & 1.145 \\
\hline 1 & 2.37 & 0.59 & 4.83 & 1.20 & 1.87 & 0.46 & 3.27 & 0.81 \\
\hline 3 & 1.86 & 0.46 & 3.12 & 0.78 & 1.02 & 0.25 & 2.53 & 0.63 \\
\hline 5 & 1.22 & 0.30 & 2.33 & 0.58 & 0.79 & 0.19 & 1.12 & 0.28 \\
\hline 7 & 0.98 & 0.25 & 1.43 & 0.35 & 0.68 & 0.17 & 0.73 & 0.18 \\
\hline 10 & 0.53 & 0.13 & 0.57 & 0.145 & 0.23 & 0.05 & 0.48 & 0.12 \\
\hline 15 & 0.01 & 0.0025 & 0.16 & 0.04 & 0.01 & 0.0025 & 0.17 & 0.04 \\
\hline
\end{tabular}

Table 8 Theoretical Maximum residue Contribution in Chickpea and Pigeon pea

\begin{tabular}{|c|c|c|c|c|}
\hline Days & $\begin{array}{l}\text { TMRC* mg } \\
\text { person }^{-1} \text { day }^{-1}\end{array}$ & $\begin{array}{l}\text { TMRC mg } \\
\text { person }^{-1} \text { day }^{-1}\end{array}$ & $\begin{array}{l}\text { Calculated TMRC } \\
\text { mg person }^{-1} \text { day }^{-1}\end{array}$ & $\begin{array}{l}\text { Calculated TMRC } \\
\text { mg person }\end{array}$ \\
\hline 0 & 0.655 & 1.425 & 0.52 & 1.145 \\
\hline 1 & 0.59 & 1.20 & 0.46 & 0.81 \\
\hline 3 & 0.46 & 0.78 & 0.25 & 0.63 \\
\hline 5 & 0.30 & 0.58 & 0.19 & 0.28 \\
\hline 7 & 0.25 & 0.35 & 0.17 & 0.18 \\
\hline 10 & 0.13 & 0.145 & 0.05 & 0.12 \\
\hline 15 & 0.0025 & 0.04 & 0.0025 & 0.04 \\
\hline
\end{tabular}

TMRC (0.04 mg person ${ }^{-1}$ day $^{-1}$, residues on day-15 being $0.16 \mathrm{mg} \mathrm{kg}^{-1}$ ) values are lower than MPI and hence the insecticide will not cause adverse effect after consumption of such chickpea green pods (Tables 7 and 8). TMRC for the recommended dose calculated in harvest grains of both chickpea and pigeon pea is $0.0025 \mathrm{mg} \mathrm{person}^{-1}$ day $^{-1}$ (residue on grains at harvest is non-detectable, which is $<0.01 \mathrm{mg} \mathrm{kg}^{-1}$ ). As the theoretical residue contribution (TMRC) was found to be less than the toxicological estimated MPI value, of $1.0 \mathrm{mg}$ person $^{-1}$ day $^{-1}$, it can be concluded that the rate of application of bifenthrin at both the doses were safe from the crop protection point of view. The pulses are a rich source of protein and are consumed almost twice daily and a regular part of Indian diet, and the MRL of bifenthrin on brassica crops as $0.02 \mathrm{mg} \mathrm{kg}^{-1}$ (Codex 2009), the residues recorded in harvest grains were below the $0.01 \mathrm{mg} \mathrm{kg}^{-1}$ thus indicating the safety to consumers and ensuring food quality.

Acknowledgements We thank the Head of the Division, Dr A. K. Dikshit for the encouragement and the facilities provided during the work. Division of Agricultural Chemicals contribution number 993.

Open Access This article is distributed under the terms of the Creative Commons Attribution Noncommercial License which permits any noncommercial use, distribution, and reproduction in any medium, provided the original author(s) and source are credited.

\section{References}

Ali MI, Karim MA (1994) Biological efficacy of some chemical insecticides against the cotton jassis, Amrasca devastans (Dist.). Entomol Generalis 18:161-167

Amweg EL, Weston DP, Ureda NM (2005) Use and toxicity of pyrethroid pesticides in the Central Valley, California, USA. Environ Toxicol Chem 24:966-972

Baskaran S, Kookana RS, Naidu R (1999) Degradation of bifenthrin, chlorpyrifos and imidacloprid in soil and bedding material at termiticidal application rate. Pesticide Sci 55:1222-1228

Codex Alimentarius Commission MRL of Pesticides (2009) EFSA Scientific report (2008) Con clusion on peer review of bifenthrin.186, 1-109. http://www.efsa.europa.eu

Fecko A (1999) Environmental fate of bifenthrin. Environ. Monitoring and Pest Mgt. Branch, Dept. of Pesticide Regulat., $830 \mathrm{~K}$ Street, Sacramento, CA 95814

Gan J, Lee SJ, Liu WP, Haver DL, Kabashima JN (2005) Distribution and persistence of pyrethroids in runoff sediments. J Environ Qual 34:836-841

Gupta S, Sharma RK, Gupta RK, Sinha SR, Rai Singh, Gajbhiye VT (2009) Persistence of New Insecticides and Their Efficacy Against Insect Pests of Okra. Bull Environ Contam Toxicol $82: 243-247$

Lee S, Gan J, Kim JS, Kabashima JN, Crowley DE (2004) Microbial transformation of pyrethroid insecticides in aqueous and sediment phases. Environ Toxicol Chem 23:1-6

Mittal PK, Adak T, Subbarao SK (2002) Relative efficacy of five synthetic pyrethroids against four vector mosquitoes, Anopheles culicifacies, Anopheles stephensi, Culex quinquefasciatus and Aedes aegypti. Indian J Malaria 39:34-38 
Mukherjee I, Gopal M, Mathur DS (2007) Behaviour of $\beta$-cyfluthrin after foliar application on chickpea (cicer aretinium L) and pigeon pea (cajanus cajan L.). Bull Environ Contam Toxicol 78:76-80

Rana ZA, Shahzad MA, Malik NA, Saleem A (2007) Efficacy of different insecticides against mustard aphid. J Agric Res 45:221

Reddy DJ, Rao BN (2002) Efficacy of selected insecticides against pests of grapevine. Pesticide Res J 14:92-99

Rushtapakornchai W, Petchwichit P (1996) Efficiency of some insecticides for controlling tobacco whitefly Bemisia tabaci and leaf miner Liriomyza trifolii on tomato Kaen Kaset Khon Kaen. Agric J 24:184-189

Sudhakar K, Punnaiah KC, Krishnayya PV (1998) Efficacy of certain selected insecticides on the sucking pest complex of brinjal. Indian J Entomol 60:241-244

Tomlin CDS (2006) The Pesticide Manual, 14th edn. Published by British Crop Protection Council, UK, pp 94-95

Ware GW (2000) The pesticide book, 5th edn. Thomson Publications, Fresno, California 